Гордеюк А. $\mathrm{O}$.

\title{
ПРОБЛЕМА ВДОСКОНАЛЕННЯ ПРАВОВОГО РЕГУЛЮВАННЯ ВЕБ-САЙТІВ І ДОМЕННИХ ІМЕН В УМОВАХ ІНФОРМАТИЗАЦІЇ СУСПІЛЬСТВА
}

У статті проаналізовано правове становище веб-сайтів і доменних імен в Україні та наукові доробки вчених щодо визначення цих специфічних об'єктів у цивільному законодавстві самостійними об'єктами права інтелектуальної власності. Запропоновано ухвалити спеціальний закон з метою удосконалення правового регулювання веб-сайтів $i$ доменних імен .

Ключові слова: веб-сайт, доменне ім'я, мережа Інтернет, ичиррове середовище, кіберпростір.

The article analyzes the legal status of websites and domain names in Ukraine and scientific works regarding the definition of these specific objects in civil law as independent objects of intellectual property. It is proposed to adopt a special law to improve the legal regulation of websites and domain names.

Keywords: website, domain name, digital environment, cyberspace, Internet.

Постановка проблеми. У результаті адаптації ринкових відносин до глобальних процесів у сфері інформатизації суспільства Інтернет набуває великого економічного значення у зв'язку з використанням у цій мережі певних об'єктів цивільних прав, зокрема об'єктів права інтелектуальної власності. Тому перед учасниками зазначених цивільно-правових відносин на сучасному етапі розвитку суспільства (тобто на етапі переходу від постіндустріального суспільства до інформаційного) постала проблема пошуку нових шляхів здійснення ефективної охорони прав інтелектуальної власності в умовах віртуалізації цих відносин.

Ураховуючи особливості правової природи об'єктів права інтелектуальної власності й специфічні риси Інтернету, який має глобальні й цифрові характеристики, що якраз і створює проблеми у сфері захисту інтелектуальної власності у такому специфічному інформаційному середовищі, метою пропонованої наукової роботи є: по-перше, аналіз чинного законодавства України щодо його можливостей здійснення ефективного правового регулювання доменних імен та веб-сайтів; по-друге, аналіз наукових доробків учених щодо доцільності визначення веб-сайтів і доменних імен у цивільному законодавстві України самостійними об'єктами інтелектуальної власності, яким притаманне використання тільки в цифровому середовищі; по-третє, на підставі аналітичних висновків висунення пропозицій щодо удосконалення правового регулювання у вище зазначеній сфері.

Стан дослідження. Правову природу об'єктів віртуального простору (зокрема, веб-сайтів і доменних імен) i проблему їх правової охорони вивчають чимало сучасних науковців, серед них Ю.С. Атаманова, Д.В. Бойко, В.В. Бонтлаб, В.С. Гура, 
P.Є. Еннан, О.О. Кирилюк, Н.І. Майданик, Н.Г. Некіт, О.І. Харитонова, Г. О. Ул'янова та ін. Більшість з них уважають, що зазначені об'єкти слід позиціонувати як об'єкти права інтелектуальної власності та створити для них належне правове забезпечення $[1 ; 2 ; 3 ; 5 ; 7]$.

Виклад основного матеріалу. Спочатку вважаємо доцільним визначитися 3 питанням коректності вживання певних ключових категорій у цьому контексті. Ідеться про те, що поряд 3 терміном «Інтернет», яким номінують певну глобальну мережу цифрового формату, уживають також такий термін, як «кіберпростір». Поняття цих категорій на сьогодні мають правове визначення в законодавстві України, і у цій роботі, на наш погляд, слід зауважити про їх співвідношення.

Отже, згідно 3 п. 11 ч. 1 ст. 1 Закону України «Про основні засади забезпечення кібербезпеки України» від 5.10.2017р., кіберпростір - це середовище (віртуальний простір), яке надає можливості для здійснення комунікацій та (або) реалізації суспільних відносин, утворене в результаті функціонування сумісних (з'єднаних) комп'ютерних систем та забезпечення електронних комунікацій з використанням мережі Інтернет та (або) інших глобальних мереж передачі даних [13].

Відповідно до ч. ст. 1 Закону України «Про телекомунікації», Інтернет - це всесвітня інформаційна система загального доступу, яка логічна зв'язана глобальним адресним простором та базується на Інтернет-протоколі, визначеному міжнародними стандартами. При цьому під інформаційною системою загального доступу розуміється сукупність телекомунікаційних мереж та засобів для накопичення, обробки, зберігання та передавання даних [15]. У цій дефініції, як уважають правознавці, акцентовано на технічному боці функціонування мережі Інтернет, тому $\epsilon$ потреба дослідити його як правову категорію, а для цього в першу чергу необхідно надати відповідне визначення, i науковці (О.I. Харитонова, Г.О. Ул'янова, А.В. Кирилюк та ін.) пропонують таке: Інтернет - це глобальна загальнодоступна інформаційно-телекомунікаційна мережа зі складною багаторівневою інфраструктурою, яка функціонує на засадах транскордонного управління та надає можливості для створення, розміщення інформації і доступу до неї, а також надання пов'язаних із цим інформаційних послуг [12, с. 161-162]. Позицію стосовно необхідності формулювання поняття Інтернету як правової категорії вважаємо конструктивною, оскільки такий підхід учених надає підстави розглядати цю мережу як правове середовище, де можуть підлягати правовій регламентації певні віртуальні правовідносини.

Виходячи зі змісту наданих вище дефініцій, можна дійти висновку, що поняття кіберпростору ширше, ніж поняття Інтернет, оскільки кіберпростір передбачає забезпечення електронних комунікацій не тільки через мережу Інтернет, а також «через інші глобальні мережі передачі даних». Тобто Інтернет розглядають та сприймають як «глобальну інформаційну мережу», «Всесвітню інформаційну павутину», а кіберпростір - як середовище, у якому вникають відносини віртуального типу в процесі використання Інтернету та інших мереж (регіональних, відомчих, корпоративних, урядових, мілітарі-мереж та ін.), які, об'єднуючись, складають кіберпростір. Таким чином, інтернет-простір або інтернет-середовище $\epsilon$ частиною 


\section{ГордеюК А. О. ПРОБЛЕМА ВДОСКОНАЛЕННЯ ПРАВОВОГО РЕГУЛЮВАННЯ ВЕБ-САЙТІВ І ДОМЕННИХ ІМЕН В УМОВАХ ІНФОРМАТИЗАЩЇ̈ СУСПІЛЬСТВА}

кіберпростору, у якому виникають, здійснюються та припиняються інтернетвідносини, котрі відповідно є відносинами віртуального типу.

Слід зазначити, що стосовно i кіберпростору, i мережі Інтернет зазвичай уживають такий термін, як «цифрове середовище», тому в контексті дослідження він також заслуговує на увагу. Легальне визначення «цифрового середовища» в законодавстві України відсутнє, але цей термін, як уважають фахівці, останнім часом увійшов не тільки у звичайну мову, а активно вживається в юридичній лексиці [16, с. 87]. Цифрове середовище більш широке поняття навіть стосовно поняття кіберпростору, оскільки охоплює не тільки віртуальний простір, у якому здійснюються електронні комунікації через різні глобальні мережі, а й притаманний також певним технічним пристроям (так званим гаджетам), які є носіями інформації поза глобальною мережею (телефони, планшети, комп’ютери, ноутбуки тощо).

Отже, виходячи $з$ вищенаведеного аналізу співвідношення категорій «Інтернет», «кіберпростір» і «цифрове середовище», уважаємо, що правомірним буде використання кожної з них у цьому контексті.

На сьогодні основне правове забезпечення у сфері інтелектуальної власності становлять Цивільний кодекс України (далі - ЦКУ), книга 4, а також Закони України «Про авторське право і суміжні права», «Про охорону прав на знаки для товарів $\mathrm{i}$ послуг», «Про промислові зразки» та ін. У ст. 420 ЦКУ визначаються об'єкти права інтелектуальної власності, що підлягають правовій охороні в Україні, а саме: літературні та художні твори; комп'ютерні програми; компіляції даних (бази даних); виконання; фонограми, відеограми, передачі (програми) організацій мовлення; наукові відкриття; винаходи, корисні моделі, промислові зразки; компонування (топографії) інтегральних мікросхем; раціоналізаторські пропозиції; сорти рослин, породи тварин; комерційні (фірмові найменування), торговельні марки (знаки для товарів і послуг) географічні зазначення; комерційні таємниці. Більшість із цих об'єктів використовується в мережі Інтернет (літературні та художні твори, комп'ютерні програми, компіляції даних (бази даних), фонограми, промислові зразки, комерційні (фірмові) найменування, торговельні марки (знаки для товарів і послуг)), а для деяких із них притаманне використання лише в кіберпросторі (зокрема для комп'ютерних програм). На думку окремих правознавців, перелік об'єктів права інтелектуальної власності, визначений законодавцем у ст. 420 ЦКУ, не можна вважати вичерпаним, оскільки, окрім комп'ютерної програми, невід'ємними від мережі Інтернет самостійними об'єктами слід уважати веб-сайти й доменні імена [2, c. $15 ; 3$, с. $16 ; 5 ; 7 ; 17]$.

У контексті цього дослідження має сенс зауважити про достатньо відомі вже концепції сучасних науковців у сфері захисту об'єктів інтелектуальної власності, що використовуються в Інтернеті, їх три: прихильники першої вважають, що охорона прав на об'єкти інтелектуальної власності є недоцільною, тому що за своєю правовою природою вони відрізняються від традиційних об'єктів цивільних прав, тому їх поширення через Інтернет не піддається контролю й регламентації, а відповідно створити для них ефективну охорону неможливо; прихильники другої концепції наголошують, що власність в інформаційному суспільстві взагалі втрачає свої позиції 
й головну роль відіграють моральні норми («інформаційна мораль»), на які слід спиратися в нових інформаційних відносинах; третій підхід фахівців до вирішення проблеми охорони прав на об'єкти інтелектуальної власності традиційний, тобто вони пропонують своєчасну адаптацію законодавства як міжнародного, так і національного до реалій цифрової епохи [6]. На наш погляд, сучасне суспільство, з огляду навіть на його достатньо високий рівень інформатизації, ще не готове відмовитися від спроб правової регламентації правовідносин в Інтернет-середовищі, у тому числі у сфері інтелектуальної власності, і при цьому керуватися тільки нормами моралі. Тому найбільш конструктивною вважаємо третю концепцію 3 вищеназваних, яка грунтується на позиції науковців, що передбачає вдосконалення правового регулювання певних правовідносин у державі, з урахуванням їх віртуалізації, у тому числі у сфері інтелектуальної власності з метою забезпечення ефективної охорони прав її суб'єктів.

Отже, одна з актуальних проблем у сфері віртуальних правовідносин - це визначення чіткого правового статусу веб-сайтів і доменних імен та їх більш детальна правова регламентація.

Веб-сайт (Інтернет-сайт) - це одиниця віртуального простору, яка в реаліях цифрової епохи привертає увагу науковців як об'єкт дослідження. Легальне визначення веб-сайту прописано в ст. 1 України «Про авторське право і суміжні права», що надає підстави на сьогодні зараховувати його до інституту авторського права. Отже, веб-сайт - сукупність даних електронної (цифрової) інформації, інших об'єктів авторського права і (або) суміжних прав тощо, пов'язаних між собою й структурованих у межах адреси веб-сайту і (або) облікованого запису власника цього веб-сайту, доступ до яких здійснюється через адресу мережі Інтернет, що може складатися з доменного імені, записів про каталоги або виклики і (або) числової адреси за Інтернет-протоколом. Законодавець у цій нормі також надає поняття вебсторінки як складової частини веб-сайту, що може містити дані, електрону (цифрову) інформацію, інші об'єкти авторського права і (або) суміжних прав тощо [11]. Виходячи зі змісту поняття веб-сайту, можна зробити висновок, що він становить складний об’єкт, у якому передбачена наявність певних елементів, що забезпечують його зміст і функціонування.

Стосовно сукупності елементів як складових веб-сайту мають місце різні думки науковців. Так, Н.І. Майданик уважає, що мінімальний набір елементів веб-сайту передбачає: дизайн; структурний розв'язок, програмне забезпечення; контент; доменне ім'я [7, с. 74]. К.А. Зеров виділяє обов'язкові елементи (контент веб-сайту, структурний розв'язок) і факультативні (дизайн, програмне забезпечення), але на доменне ім'я він указує як на самостійний об'єкт, призначений для індивідуалізації учасників цивільного обігу в мережі Інтернет, пов'язаний із товарними знаками (торгівельними марками), а не 3 інститутом авторського права [5, с. 29-30]. Ю.С. Атаманова, досліджуючи проблему захисту прав інтелектуальної власності у мережі Інтернет, уважає, що досягнення формальної й змістової єдності веб-сайтом здійснюється завдяки трьом його складникам, а саме: 1) програмним та апаратним засобам (серверним програмним засобам, програмним засобам сайту); 2) адресі в 
мережі Інтернет або доменному імені; 3) інформаційному наповненню, яке охоплює текстову інформацію, графічну інформацію, аудіовізуальну інформацію [1, с. 7].

3 огляду на легальне поняття веб-сайту й вищенаведені думки фахівців, можна схарактеризувати його правову природу й визначити таке: по-перше, слід позиціонувати веб-сайт як самостійний об'єкт права інтелектуальної власності, який створюється 3 метою розміщення певної інформації в мережі Інтернет у різному наочному виразі; по-друге, він серед своїх елементів передбачає наявність інших об’єктів права інтелектуальної власності (зокрема об'єктів авторського права і (або) суміжних прав), може мати певний дизайн, який у свою чергу може визнаватися промисловим зразком, а також веб-сайт ідентифікується шляхом використання доменних імен, які слід розглядати також як самостійні об’єкти інтелектуальної власності. Законодавець зробив певний крок стосовно правової регламентації вебсайту, коли визначив його поняття у вищезазначеному Законі, однак для здійснення більш ефективного правового регулювання веб-сайту як об'єкта права інтелектуальної власності цього не достатньо. Доцільним було б, перш за все, внесення веб-сайту до переліку об’єктів права інтелектуальної власності, що надається в ст. 420 ЦКУ, і таким чином визначення його самостійного правового статусу [17].

Щодо доменних імен, то на наш погляд, слід погодитися з думкою науковців (зокрема К.А. Зерова, В.В. Бонтлаба, Д.В. Бойко), які вважають доменне ім'я самостійним об'єктом, котрий має сенс відокремлювати від веб-сайту, а також від інших об'єктів інтелектуальної власності. Слід зазначити, що доменні імена (domain name) фахівці визначають як засоби адресації інформаційного ресурсу юридичних чи фізичних осіб у кіберпросторі, що здійснюють ідентифікаційну функцію, аналогічну тій, що виконують для користувачів товарами або послугами такі об'єкти інтелектуальної власності, як знаки для товарів та послуг (торговельні марки) або комерційні (фірмові) найменування $[2$, с. 2-3, с. 9; 3, с. 4]. Така подібність функціоналу названих об'єктів не могла не призвести до виникнення певних правових колізій. Учені дійшли висновку, що для усунення цих колізій необхідно розмежовувати правовий режим їх охорони, виходячи із неоднаковості правової природи знаків для товарів і послуг (торгівельних марок) та доменних імен. Правове становище доменного імені певною мірою визначено Законами України «Про охорону прав на знаки для товарів і послуг», «Про телекомунікації», а також у «Правилах домену.UA» та в Порядку підключення до глобальних мереж передачі даних, затвердженого Постановою Кабінету Міністрів України від 12.04 .2002 р. № $522[9 ; 11 ; 14 ; 15]$.

Так, відповідно до ч. 1 ст. 1 Закону України «Про телекомунікації», домен частина ієрархічного адресного простору мережі Інтернет, яка має унікальну назву, що їі ідентифікує, обслуговується групою серверів доменних імен та централізовано адмініструється [15]. Зміст поняття «домен», наданий у цьому Законі, підтверджує думку правознавців стосовно призначення доменних імен як засобу індивідуалізації інформаційного ресурсу в мережі Інтернет або, інакше кажучи, як засобу індивідуалізації адресного простору мережі Інтернет [3, с. 3]. 
У ст. 1 Закону України «Про охорону прав на знаки для товарів і послуг» надається таке поняття доменного імені: це ім'я, що використовується для адресації комп’ютерів і ресурсів в Інтернеті. Як самостійний об'єкт інтелектуальної власності доменне ім'я в цьому Законі не позиціонується, його законодавець визначає тільки як один із способів використання знаку для товарів і послуг (торгівельної марки), зокрема у п. 4 ст. 16 Закону прописано, що «...використанням знаку визнається його використання, у тому числі, в Інтернет» [14]. Виходячи з положення вищезазначеного Закону, знак для товарів і послуг (торговельна марка) і доменне ім'я ототожнюються як об'єкти інтелектуальної власності, що індивідуалізують учасників цивільного (господарського) обігу, і різниця між ними тільки в тому, що перші ідентифікують певні товари, послуги, виконання роботи в реальному світі, а другі - у віртуальному. Але $з$ позицією законодавця складно погодитися, i, на наш погляд, принципове юридичне значення має не тільки те, що ці об'єкти можна розмежувати залежно від середовища їх застосування, а також слід розмежовувати за їх правовою природою, про що вже зазначалося вище. Так, по-перше, товарні знаки (торговельні марки) $\epsilon$ дійсними тільки на території їх реєстрації, доменним же іменам притаманна транскордонність [2, с. 6]. По-друге, знаки для товарів і послуг (торговельні марки) використовуються суб' єктами приватного права (фізичними та юридичними особами) для їх ідентифікації в цивільному (господарському) обігу, а доменні імена згідно 3 п. 1.8. «Правил домена.UA» поділяються за їх призначенням на дві категорії: публічні, тобто ті, що адмініструються в інтересах громадськості; приватні, тобто такі, що адмініструються певною особою у своїх власних інтересах [10]. По-трете, у цих об'єктів різне позначення, відповідно до ст. 5 Закону України «Про охорону прав на знаки для товарів і послуг», ст. 492 ЦКУ у якості товарного знака (торговельної марки) можуть використовуватися будь-які позначення чи комбінація позначень, зокрема слова, у тому числі власні імена, літери, цифри, зображувальні елементи, кольори та комбінація кольорів $[14 ; 17]$. А як доменне ім'я може мати місце буквеноцифровий вираз, що ідентифікує будь-який комп’ютер абонента в мережі Інтернет, тобто використовується лише буквено-цифрова послідовність символів 3 певною довжиною, зокрема не більше 63 символів (відповідно до Регламенту реєстрації імен у домені com.ua та з огляду на результати дослідження, зокрема Д.В. Бойко) [8, с. 41; 2, с. 6]. До того ж слід зазначити, що відсутність чіткої правової ідентифікації доменних імен призвела до так званого кіберсквотингу (від англ. Cybersquatting піратство, захоплення), або кіберзахоплення доменних імен недобросовісними суб'єктами, що використовують їх у подальшому для власних комерційних цілей [6]. У ч. 2 ст. 20 Закону України «Про охорону прав на знаки для товарів і послуг» прописано, що порушенням прав власників свідоцтва (що є охоронним документом права інтелектуальної власності для власника знаку для товарів та послуг (торгівельної марки)) вважається використання без їх згоди в доменних іменах знаків i позначень відповідно до п. 5 ст. 16 цього ж Закону [14]. Однак ця норма надає можливість власникам знаків для товарів i послуг відстоювати свої права установленими законодавством способами, але не враховує інтереси власників доменних імен. 
Уважаємо, що вищенаведені аргументи надають підстави для висновків про необхідність удосконалювати правове регулювання у сфері охорони й використання доменних імен, а саме йдеться про визначення в законодавстві України окремого правого режиму охорони доменних імен. Зокрема слушною є пропозиція деяких науковців, 3 огляду на призначення доменного імені як засобу індивідуалізації учасників цивільного обігу, товарів і послуг у Всесвітній мережі Інтернет, визнати його самостійним об'єктом права інтелектуальної власності й включити до переліку об’єктів права інтелектуальної власності, визначеного у ст. 420 ЦКУ [2, с. 9; 3, с. 17].

Також заслуговує на увагу наукова позиція, зокрема В.В. Бонтлоба, про необхідність створення доменного законодавства, а саме прийняття закону «Про доменні імена», а в ЦКУ - виділення окремого розділу, де доцільно було б урегулювати правові аспекти виникнення прав на доменні імена та зміст прав власників доменних імен [3, с. 5]. Такі кроки законодавця, звісно, здатні забезпечити більш фундаментальну правову регламентацію доменних імен і відокремити їх правовий режим від інших об'єктів індивідуалізації в системі права інтелектуальної власності. Однак вважаємо, що більш раціональним було б не створення окремого доменного законодавства, а ухвалення спеціального закону, який передбачатиме правову регламентацію об'єктів права інтелектуальної власності, що не використовуються поза мережею Інтернет, зокрема веб-сайтів і доменних імен. Такий закон дозволив би: по-перше, виділити правовий інститут у системі інтелектуальної власності, норми якого мали б здійснювати спеціальне правове регулювання щодо використання й охорони зазначених специфічних об'єктів; по-друге, не захаращувати додатковими правовими конструкціями ЦКУ. На сьогодні веб-сайт і доменне ім'я належать різним інститутам, веб-сайт - інституту авторського права, а доменне ім'я, якщо його не розмежовувати зі знаками для товарів і послуг, зараховують до об'єктів інтелектуальної власності, що індивідуалізують учасників цивільного обігу (тобто до інституту права промислової власності). Окремий спеціальний закон здатний посилити правовий механізм державного регулювання веб-сайтів і доменних імен i, таким чином, забезпечити можливість власникам цих об'єктів інтелектуальної власності в умовах активної віртуалізації відносин у суспільстві більш ефективно захищати свої права.

Висновки. Отже, після проведеного аналізу чинного цивільного законодавства, зокрема 3 права інтелектуальної власності, можна зробити висновок, що воно має низку прогалин у сфері правового регулювання веб-сайтів і доменних імен, тому потребує певної адаптації до реалій цифрової епохи. Творчі доробки вченихцивілістів, а також визначення понять веб-сайту й доменного імені (домену), подані відповідно в Законах України «Про авторське право і сумежні права», «Про телекомунікації», «Про охорону прав на знаки для товарів і послуг», надають можливість схарактеризувати правову природу цих об'єктів, а активна інформатизації суспільства й практика використання зазначених об'єктів у віртуальних відносинах диктують необхідність позиціонування їх у законодавстві як самостійних об'єктів права інтелектуальної власності. Тому, по-перше, уважаємо, що 3 огляду на пропозицію науковців щодо визначення доменного імені та веб-сайту як об'єктів 
інтелектуальної власності у ст. 420 ЦКУ слід додати їх у перелік об'єктів інтелектуальною власності, прописаний у цій нормі, що має закріпити самостійний правовий статус обох об'єктів. По-друге, ефективне правове регулювання веб-сайтів і доменних імен недостатньо здійснювати тільки на рівні зазначених вище законів, де для них виділено тільки кілька норм, тому доцільним було б ухвалення окремого спеціального закону, нормами якого має буде забезпечена правова регламентація вєбсайтів і доменних імен як специфічних об'єктів права інтелектуальної власності, яким притаманне використання лише в цифровому середовищі.

\section{Лiтература:}

1. Атаманова Ю. С. Захист прав інтелектуальної власності у мережі Інтернет: світовий досвід та вітчизняні перспективи // Право та інновації. 2014. № 3. С. 7.

2. Бойко Д. В. Правова природа доменних імен Інтернет : автореф. дис... канд. юрид. наук. Харків, 2005. 19 c.

3. Бонтлаб В. В. Цивільно-правове регулювання доменних імен : автореф. дис...канд. юрид. наук. Киї, 2006. 20 с.

4. Жуванов Д., Стогній $Є$. Проблема доменних імен в Украйні. URL : http : // www.romantnro.b12/uu/library/article.domenes_in_ua.htm/

5. Зеров К. О. Веб-сайт як непоіменований об'єкт авторського права // Науковий вісник міжнародного гуманітарного університету. 2013. № 6-3. Т. 2. С. 28-30.

6. Інтелектуальна власність в епоху Інтернету. URL : https:com// pidruchniki19310710/economica/intelektualna_vlasnist_epohu internetu.

7. Майданик H. I. Web-сайт в мережі Інтернет як особливий об'єкт авторського права // Юридична Украӥна : Правовий часопис. 2008. № 12. С. 73-80. C. $40-44$.

8. Некіт К. Г. Доменне ім'я як об’єкт циивільних прав // Часопис изивілістики. 2007. Вип. 23.

9. Постанова Кабінету Міністрів України від 12.04.2002 № 522 Про затвердження порядку підключення до глобальних мереж передачі даних URL : https: 2zakon.rada.gov.ua/laws/shows/522$2002 n$.

10. Правила домену. UA від 27.07.2001 p. URL: https : //www/uknames.com/u.

11. Про авторське право і суміжні права : Закон України від 23.12.1993 № 3792-12 Відомості Верховної Ради України. 1994. № 13. Ст. 64.

12. Проблемні питання визначення правової природи $i$ структури правовідносин інтелектуальної власності, що виникають у мережі Інтернет / О. І. Харитонова, Г. О. Ульянова, А. В. Кирилюк та ін. // Наукові прачі НУ"ОЮА". 2015. T. 17. С. 159-200.

13. Про основні засади забезпечення кібербезпеки в Украӥні : Закон Украӥни від 05.10.2007 № 2163-VIII. Відомості Верховної Ради України. 2017. № 45. Ст. 403.

14. Про охорону прав на знаки для товарів і послуг : Закон України від 15.12.1993 № 3689-12. Відомості Верховної Ради України. 1994. № 7. Ст. 3.

15. Про телекомунікаиії : Закон України від № 18.11.2003. 1280-IV. Відомості Верховної Ради України. 2003. № 12. Ст. 155.

16. Савич С. С. Авторське право у иифровому середовищі: проблема монополії правовласника та забезпечення умов вільного використання творів // Бюлетень Міністерства юстиції України. 2015. № 1. C. 86-92.

17. Цивільний кодекс України від 16.01.2003 // Відомості Верховної Ради України. 2003. № 4044. Cm. 356 . 


\section{ГордеюК А. О. ПРОБЛЕМА ВДОСКОНАЛЕННЯ ПРАВОВОГО РЕГУЛЮВАННЯ ВЕБ-САЙТІВ І ДОМЕННИХ ІМЕН В УМОВАХ ІНФОРМАТИЗАЩЇ̈ СУСПІЛЬСТВА}

\section{References:}

1. Atamanova, Yu.E. (2014), “Zahyst prav intelektual'noyi vlasnosti u merezhi Internet: svitovyy dosvid I vichiznyani perspektyvy" ["The protection of the intellectual property rights on the Internet: world experience and domestic prospects"], Pravo ta innovatsiya, No 3, p. 7.

2. Boyko, D. V. (2005), Pravova pryroda domennyh imen Internet: avtoref. dys... cand. yurid. nauk [Legal nature of domain names: dissertation, Ph.d in Law], Kharkiv, 19 p.

3. Bontlav, V.V. (2006), Tsyvil'no-pravove regulyuvannya domennyh imen; avtoref. dys...cand. yurid.nauk [The civil legal regulation of domain names: dissertation, Ph.d in Law], Kyiv, 20 p.

4. Zhuvanov D., Stogniy E. (2003), Problema domennyh imen v Ukrayini [The problem of domain names in Ukraine], available at: https: //www.romantnro.b12/uu/library/article.domenes_in_ua.htm/

5. Zerov, K. O. (2013), "Veb-sayt yak nepoimenovanyy obe'kt avtors'kogo prava" ["Website as unnamed object of copyright"], Naukovyy visnyk mizhnarodnogo gumanitarnogo universytety, No. 6-3, Vol. 2, pp. 28-30.

6. Intelektual'na vlasnist' $v$ epohu Internet [Intellectual property in the era of Internet], available at: https:com//19310710/economica/intelektualna_vlasnist_epohu_internetu.

7. Maydanik, N. I. (2008), "Veb-sayt u merezhi Internet yak osoblyvyy ob'ect avtors'kogo prava" ["The website as an special object of copyright"], Yurydychna Ukrayina : pravovyy chasopys, No 12, pp. 78-80.

8. Nekit K. G. (2007), "Domene im'ya yak ob'ect tsyvilnyh prav" ["The domain name an object of civil rights"], Chasopys tsyvilistycy, vol. 23. pp. 40-44.

9. Postanova Kabinetu Ministriv Ukrayiny vid 12.04.2002 No 522 Pro zatverdzhenya poraydku pidklyuchennya do globalnyh merezh peredachi dannyh [Cabinet decree from 12.04.2002 № 522 About approval of the order of connection to global data network], available at: https: 2zacon.rada.gov.ua/laws/show/522-2002n.

10. Pravyla domenu.UA (2007) [The rules of domen .UA], available at: https://www.uknames.com/u.

11. "Pro avtorske prarvo i sumizhni prava" ["About copyright and related rights"], Zakon Ukrayiny (23.12.93 No 3792-12), Vidomosti Verkhovnoyi Rady Ukrayiny (13), 64 (in Ukr).

12. Kharytonova, O. I., Ul'yanova, H. O., \& Kyrylyuk, A. V. et all. (2015), "Problemni pytannya vyznachennya pravovoyi pryrody I structury pravovidnosyn intelektual'noyi vlasnosti, shcho vynykayut u merezhi Internet" ["Problematic issues of determining the legal nature and structure of intellectual property rights arising in the Internet"], Naukovi pratsi NU OYUA, V. 17, pp. 159-200.

13. "Pro osnovni zasady zabezpechennya kiberbezpeky v Ukrayini" ["About basic ambush cybersecurity in Ukraine"], Zacon Ukrayiny (05.10.2007 No 2163-VIII), Vidomosti Verkhovnoyi Rady Ukrainy, (48), article103. (in Ukr.)

14. "Pro okhoronu prav na znaky dlya tovariv i posluh" ["On the Protection of Rights to Trademarks for Goods and Services"], Zakon Ukrayiny (15.12.1993 No 3689-12), Vidomosti Verkhovnoyi Rady Ukrayiny, (7), article 36. (in Ukr.)

15. "Pro telekomunikatsiyi" ["About telecommunications"], Zakon Ukrayiny (18.11.2003 No 12804), Vsdomosti Verkhovnoyi Rady Ukrayiny, (12), article 155. (in Ukr.)

16. Savych, S. S. (2015), Avtors'ke parvo u tsyfrovomy seredovyschi: problema monopoliyi pravovlasnyka ta zabezpechennya ymov vil'nogo vykorystannay tvoriv /Copyright in digital environment: the problem of monopoly of the owner and ensuring conditions of free use of works], Byuleten' Ministerstva yustytsiyi Ukrayin, No 1, pp. 86-92.

17. Tsyvil'nyy kodeks Ukrauiny [The Civil Code of Ukraine]. (16.01.2003) Vidomosti Verkhovnoyi Rady Ukrayiny, (40-44), article 356. (in Ukr) 


\section{Alla Hordeiuk}

\section{PROBLEM OF IMPROVING LEGAL REGULATION OF WEBSITES AND DOMAIN NAMES IN CONDITIONS OF SOCIETY INFORMATIZATION}

The article analyzes the legal status of websites and domain names and scientific developments of scientists regarding the feasibility of determining them as independent objects of intellectual property.

As follows from the analysis of national legislation, some certain gaps have been defined and the ways to eliminate them have been recommended in order to improve the legal regulation of websites and domain names. The position of scholars regarding defining websites and domain names as independent objects of intellectual property in the civil law has been considered reasonable and rational, as well as adding them to article 420 of the Civil Code of Ukraine, which specifies objects of intellectual property subject to legal protection in the state. There was a suggestion to adopt a special law, which should implement legal regulation of specific objects of intellectual property that are used only in virtual space, and will provide an effective system for protecting the rights of owners of websites and domain names.

Keywords: website, domain name, Internet, digital environment, cyberspace.

\section{Алла Гордеюк}

\section{ПРОБЛЕМА УДОСКОНАЛЕННЯ ПРАВОВОГО РЕГУЛЮВАННЯ ВЕБ-САЙТІВ І ДОМЕННИХ ІМЕН В УМОВАХ ІНФОРМАТИЗАЦІЇ СУСПІЛЬСТВА}

У статті проаналізовано правове становище веб-сайтів і доменних імен та наукові доробки вчених щодо доцільності визначення їх самостійними об'єктами права інтелектуальної власності.

У результаті аналізу сучасного стану вітчизняного законодавства стосовно правової регламентації зазначених вище об'єктів визначено певні прогалини та рекомендовано шляхи їхнього усунення 3 метою вдосконалення правового регулювання веб-сайтів і доменних імен. Визнана обгрунтованою й доцільною позиція науковців щодо визначення веб-сайтів і доменних імен самостійними об'єктами інтелектуальної власності в цивільному законодавстві та доповнення ними ст. 420 Цивільного кодексу України, де прописано перелік об’єктів інтелектуальної власності, що підлягають правовій охороні в державі й таким чином закріплення правового статусу веб-сайтів і доменних імен. Запропоновано ухвалити спеціальний закон, який має здійснювати правове регулювання специфічних об'єктів інтелектуальної власності, що не використовуються поза мережею Інтернет, і 
забезпечить ефективну систему охорону прав власників веб-сайтів і доменних імен.

Ключові слова: веб-сайт, доменне ім'я, Інтернет, циифрове середовище, кіберпростір.

Hordeiuk Alla - Ph.d in law, Associate Professor, Associate Professor of the Department of Law Faculty of Humanities of National Aerospace University "Kharkiv Aviation Institute".

Гордеюк Алла - кандидат юридичних наук, доцент кафедри права гуманітарного факультету Національного аерокосмічного університету ім. М. С. Жуковського «Харківський авіаційний інститут».

Надійшла до редакції 27.05.2019. Розглянута на редколегії 14.06.2019.

\section{Рецензенти:}

Доктор юридичних наук, професор, професор кафедри загальноправових дисциплін Харківського національного університету внутрішніх справ Зозуля I. В.

Кандидат юридичних наук, доцент, доцент кафедри права гуманітарного факультету Національного аерокосмічного університету ім. М. Є. Жуковського «ХАІ» Гуцу С. Ф. 